\title{
Konrad NIKLEWICZ
}

DOI : $10.14746 / \mathrm{pp} .2016 .21 .4 .15$

Brussels

\section{EU's pressing communication challenge}

\begin{abstract}
In order to help rebuilding popular support and trust towards the European Union, EU's institutions need to substantially change their communication strategy. Recent political developments, especially 2016 Britain's referendum on the EU Membership, have shown that the old model of reaching to citizens no longer meets expectations. Drawing on available data and ex-post evaluations of promotional campaigns, this article examines possible ways of enhancing the way EU connects to citizens. The paper concludes that the focus should be shifted from mediated communication to a more direct one, including massive use of online social platforms and corporate-style promotional campaigns. The EU's own experiences confirm the efficiency of the latter.
\end{abstract}

Key words: European Union, communication, political marketing, social media

\section{Introduction}

$\mathbf{T}$ he European Union entered the year 2017 in a state of a deep existential crisis. "Never before have I seen so much fragmentation, and so little commonality in our Union" - declared the European Commission's President Jean-Claude Juncker in his "State of the Union" annual address to the European Parliament, on September $14^{\text {th }} 2014$ (State of the Union, 2016, p. 6).

The crisis in question has many roots, insufficient and ineffective communication with EU citizens is beyond doubt one of them.

In order to help rebuilding popular support and the trust towards the European Union, EU's institutions need to substantially change their communication strategy. Recent political developments, especially 2016 Britain's referendum on the EU membership, have shown that the old model of reaching to citizens - based on mediated communication and intensive cooperation with the "old" media (print press, radio, TV news outlets) - no longer meets expectations.

There are many possible ways of enhancing the way EU connects to citizens. This paper claims that one particular modification of the communication strategy is needed: shifting the focus from mediated communication to corporate-style promotional campaigns and better and more intensive use of online social platforms. The verification of this hypothesis' veracity will be based on available analysis of past EU's promotional campaigns (referring to the EU's Cohesion Policy). It will be discussed whether a direct communication with citizens, circumventing the traditional media, brings substantial results. In the context of recent political events, the changing patterns in mass communication and growing role of online social platforms will also be discussed. 


\section{The importance of communication}

The European Union institutions, like all public bodies, are obliged to communicate their activities to the public. Informing the members of the public has become one of unquestionable duties of all governing entities, on all levels: transnational, national and local (Maćkowska, 2005, p. 325). The EU is not different in this respect from any other form of public governance. Without access to the relevant information, provided through communication, citizens are unable to evaluate European Union's performance and, in consequence, to make their own judgment on EU's merits - or lack of them (Elenbaas et al. 2012, pp. 728-755). Furthermore, communication is a prerequisite for building institutions' reputation, which is nothing else than assessment made by public, based on information it receives (Stroeker, van der Graaf, Buiskool, 2014, p. 14). Without communication, there cannot be positive reputation. And without positive reputation, it is not possible to exert power in the democratic context. This explains why public institutions' efforts to manage their reputation and to improve their "brand" through communication has become one of the elements if their daily business duties (Ryniejska-Kiełdanowicz, 2007, p. 7). It is also true for European institutions: some scholars argue that the future of European integration hinges upon public support (Vliegenthart et al., 2008, p. 416).

\section{The evolution of the European communication strategies}

The EU institutions' have been developing their communication strategies over time, in parallel to changing construction, size and level of integration of the European community. At the very beginning of the European integration $(50 \mathrm{~s}$ and $60 \mathrm{~s}$ of the last century), the institutions were overshadowed by the national bodies and limited their communication activities to an absolute minimum. However, as the competences of the European bodies (Commission, Parliament and the Council) grew and started to affect the daily life of millions of Europe's citizens, so did the inevitability of reaching out to public opinion.

The current European Union's communication strategy is based on the underlying philosophy elaborated in the first half of 2000s. It has been relying on fundamental assumption: first, that the transparency is the key to connecting with citizens. Second: that mediated communication, achieved through cooperation with mass media (print press, TV, radio) and other third parties, such as Non-Governmental Organisations, is the best way to guarantee EU's proper visibility and, thus, to allow EU institutions to connect with citizens, allowing them to find the information they need (Lodge, Sarikakis, 2013, pp. 21, 24). The aforementioned approach, based on two pillars, was supposed to respond to one particular problem, identified by the European Commission as early as in 1994: citizens' lack of understanding of how European construction works leading to decreasing public support (Stroeker, van der Graaf, Buiskool, 2014, p. 17). The process of EU's losing the popular support, stretched over years, was clearly manifested by a string of political events, starting with 1992 Danish rejection of the Maastricht Treaty and 2005 French and Dutch rejection of the EU's Constitutional Treaty (also by the way of referendum). By that time (2005) the efficiency of the previous European communica- 
tion was openly questioned by scholars: researchers alarmed that the EU communication had been failing for long and that negative consequences had been building up, resulting in growing citizens' disenchantment (de Vreese, 2003, p. 5, 7). It is worth noting that in 2006 the European Commission reasserted own view of situation formulated 12 years earlier and once more admitted that the growing gap between the EU, European institutions and citizens posed a problem (White Paper, 2006, p. 2).

The building blocks of the new strategy were put in place one after the other. The first attempt was made in 2002, when Romano Prodi's Commission adopted the "Information and Communication Strategy" (Communication from the Commission, 2002). In 2004, first ever EU Commissioner for communication was appointed (Swedish Margot Wallstrom taking the role). Following her nomination, no less than four documents were adopted, detailing the effort: an Action Plan, two Communications and a White Paper. The aim of the effort was to strengthen the output legitimacy of the EU and to bring its institutions closer to the people (Monaghan, 2008, p. 18). Transparency was the keyword, in accordance with the underlying philosophy. Strategic documents adopted in the period 2002-2007 also showed Commissions' strong belief in the concept of transnational European public opinion, the one sharing topics, timing and uniting citizens in different EU Member States. The 2002 Commission's "Strategy" aimed at promoting what it called "participation of the general public in the great European debate," while the 2007 Commissions communication openly mentioned the goal of setting of the European public sphere (Communication from the Commission, 2002, p. 10; Communicating Europe, 2007, p. 10).

\section{Limited results of mid-2000 communication strategy}

However, it is disputable whether the strategy adopted in 2000s was able to achieve the goals and solve the problem of EU's disconnect with citizens. First, the very existence of "European public sphere" is questioned. As W. Przybylski noted, Europeans tend to discuss Europe within boundaries of their home countries. Instead of a single great European debate, there are 28 national debates going on in parallel, each one different from another (Przybylski, 2016, pp. 75, 78).

More importantly, available studies suggest that the adopted model of communicating the EU - despite it being strongly focused on cooperation with third parties and mediated communication - failed to galvanize media's attention (Stroeker, van der Graaf, Buiskool, 2014, p. 95). This critical assumption is corroborated by the proven data, showing that not much changed in terms of EU's overall visibility in the mass media. Relatively low in 1970s, 80s and 90s (de Vreese, 2003, p. 13), it remained low in the first in the beginning of the 2010s (Boomgaarden et al., 2013, p. 609).

There are many reasons for the limited media attention, but two of them seem most relevant: insufficient quality of the content provided and sub-optimally targeted journalists. From the very outset the content of the EU's communication was intentionally impartial and emotion-free. As understandable as it is, such "neutral" and facts-only content proved to be unsatisfying for the mass media and badly fit into the conflict-oriented environment of the XXI-century media (Valentini, 2013, pp. 8-10). Studies that included 
polling of the Brussels-based press corps confirmed that the majority of EU correspondents considered the messages they received as "boring" and "lacking juice", hence news unworthy (Martins, 2012, pp. 305-322). The intentional impartiality of the EU message was the reflection of the EU Institutions' nature and the nature of the decision-making process, always based on reasoned opinions, compromise, fairness etc. and requiring language that would be accepted by all parties interested. Nevertheless what works in interinstitutional and intra-governmental relations, does not necessarily proves effective in public communication.

It is not only the low visibility in the media that suggests the failure of the communication efforts conceived in the first 2000s (and applied until very recently). Fading popular support for the European integration and for the European institutions also imply that the new communication strategy failed to properly address the problem identified in 1990s and to reverse the trend in public opinion. Eurobarometer statistics are telling. In 2007 as much as 57 per cent of Europeans declared trust towards the European Union. In some countries, the levels of trust exceeded 60 per cent (Belgium - 73, Estonia - 72, Netherlands - 69 and Poland - 68 (Standard Eurobarometer, 2007, p. 52). Nearly ten years later, only 33 per cent of polled Europeans tended to trust the Union, 55 per cent declared otherwise. In no European country the level of trust exceeded 60 per cent (highest results recorded in Lithuania - 58, and Malta - 52 (Standard Eurobarometer, 2016, p. T43).

\section{Brexit: the ultimate case-study of pro-European communication failure}

The 2016 referendum campaign in Britain (together with the referendum's result) might be interpreted as yet another clue suggesting that the past way of communicating Europe was not nearly effective as needed. Although European institutions purposely did not take part in the campaigning, both the narrative and tactics used by the proEuropean camp ("Britain Stronger In Europe" campaign, abbrev. "Stronger In") strongly resembled what is at the core of EU institutions' communication routine. The "Stronger In" campaign was focused on verifiable facts, while the opposite camp ("Vote Leave, take control" campaign, abbrev. "Vote Leave" and the other campaign, called "Leave. EU") based its campaigning narrative on emotions and to a large extent disregarded facts (Viener, 2016). Brexit supporters exploited deep-running emotions of the British society. Two elements were played most heavily: immigration and identity issues (The Politics, 2016, p. 12) and fallout from globalisation (equalled with the European Union). The "Stronger In" campaign leaned on detailed prognosis of possible economic consequences, should Great Britain leave the EU, while the "Vote Leave" \& "Leave.EU" camp used false arguments, like the claim that Britain pays 350 million pounds weekly to the EU budget (Cohen, 2016).

The "Vote Leave" \& "Leave the EU" camp was also better at using the new channels of communication, mainly the online social media (Facebook, Instagram, Twitter, You Tube etc.). On Twitter the pro-Brexit camp was able to create a momentum and outnumber the "Remain" in a staggering proportion (for every single pro-EU tweet, there were seven pro-Leave). On Instagram, another popular social platform, the proportion were 
similar: of all referendum-related posts, 35 per cent were in favour of "Leave", only seven per cent sided with "Remain". Some scholars claim that ignoring the power of social media led to "Remain" failure, as the reason-based arguments did not reach the people, while the emotional, simple messages of the "Leave" spread (Maddalena, 2016, pp. 245-252). Further studies are necessary to understand whether such disproportion was the result of users' genuine engagement or better use of sponsored content/paid users on social media in question. It has been however confirmed that "Leave" camp was spending a substantial part of its budget during the campaign on social media (Hodson, 2016). It is worth noting that British tabloid press substantially added to the "Vote Leave" ("Leave.EU") campaign success. According to the study conducted by Loughborough University's Centre for Research in Communication and Culture, some of the biggest-circulation titles ("Daily Mail", "Daily Telegraph" and "The Sun") openly called for Brexit (Hard Evidence, 2016). The opinion-making papers (including "The Times" and "Financial Times") declared their support for "Remain". In total, multiplying the readership by the number of items, 82 per cent of the print media coverage was more or less inclined to "Vote Leave" and only 18 per cent - for "Stronger In".

\section{The growing importance of the online media}

Changing communication environment is one of the factors that greatly influence the efficiency and, therefore, the impact of European communication. The pace of changes is quick and it turns the EU institutions' communication structure - oriented mostly towards the "old" media and past types of communication activity - less relevant. According to the Eurobarometer data, already in 2015 the Internet-based media were considered to be the third most important source of information (TV and radio topping the list). On average 59 per cent of the EU's citizens declared using the Internet on the daily basis (Standard Eurobarometer 84, 2015, p. 15). In some countries, the proportion was much higher: 86 per cent in the Netherlands, 85 per cent in Denmark and in Sweden. One particular type of online medium has been rising in importance most substantially: the so-called social media (social platforms). In 2015 half of Europeans used social media at least once a week - 15 percentage points more than in 2011. According to the 2016 data, in several EU Member States the biggest part of population consider social media as "trustworthy": 53 per cent in Poland, 46 in Romania, 43 in Slovenia. Latest Eurobarometer findings show the younger respondents are, the more often they consider social media as reliable source of information - which suggests that in the future, the importance of new types of online based media will grow further (Special Eurobarometer 452, 2016, p. 31), as it already happens in the United States, where 50 per cent of Americans aged 29 or less use online platforms as the primary source of information (Mitchell, 2016, p. 4). TV consumption (all types: cable, local, national included) among 18-29 year old Americans is less intensive (27 per cent). By contrast, it is 72 per cent for the 50 years or more generation. For young Americans, print press is at the bottom of the list of media sources -5 per cent of the young generation consider printed newspapers as a major source of information (Mitchell, 2016, p. 4). Today's world is a world of Snapchat, Facebook, WhatsApp, Twitter, Instagram or Uncyclopedia (Wikipedia-styled 
site publishing fake news on purpose). In this world the information travels in waves, in split-second time. People pick up only the bites of the message, the ones that reaffirm their own feelings and/or raise emotions.

\section{New ways of communicating Europe: best practices}

Should attempts be made to increase the efficiency of the European communication (this paper strongly advocates it), the aforementioned context must be taken into consideration. Two assumption seem to impose themselves. First, the past model of communication - judged by its results - appears to be suboptimal. Second, the new model of communication should be aligned with the changed context of communication environment. Most importantly, the ascent of the social media as the primary source of the information should addressed.

There are examples of the successful European communication efforts the EU institutions can draw from, like promotional campaigns related to the use of European Funds. The latter, in line with the European Parliament and Council Regulation 1303/2013 (Regulation, 2013, pp. 320-469), are obligatory. Beneficiaries of EU funding on all levels (cross-border, national, regional and local) are obliged not only to inform and to promote of concrete projects and availability of EU-funded support programmes, but also to promote their impact. The European Funds provide necessary funds to finance the appropriate communication, making it easier for beneficiaries to use efficient ways of promotion, including country-wide multimedia campaigns.

The campaigns in Poland are particularly illustrative for their efficiency, as measured by the ex-ante and ex-post evaluations.

The first example is the 2008 promotional campaign „Dobra informacja na dobry początek” („Good information for a good start”), launched in November and ended in December 2008. It consisted of TV ads and billboard advertising in 51 cities. The effects of the campaign have been measured using two quantitative researches (polls), conducted one month before and one month after the "Good information for a good start" campaign (each of the polls had an 1011 persons sample, representative for Poland's population aged $15+$ ). 47 per cent of the population had seen at least once the TV ad, 9 per cent at least once had seen the billboard. Results: the overall knowledge about the European Funds increased by a noticeable factor. After three months of campaign, the number of people declaring that the information about the European Funds are not easily accessible decreased, from 32 to 25 per cent (Badanie omnibusowe, 2009, pp. 6, 9).

Another example of a successful communication effort is the 2014 "Prawdziwe historie" ("True stories") campaign, run in the first half of 2014. Its goal was to promote the added value of EU funding, positive change it brings into ordinary people life. Thanks to the available funding, "True stories" campaign was massively multimedia: it was aired in TV, radio and online (including social media). The ex-post evaluation showed positive effects of the campaign. It raised the awareness of the European Funds in Poland by five percentage points and contributed to the positive perception of EU Cohesion funds (Badanie poziomu, 2014, p. 6). 
Although it is difficult the estimate the exact impact of the EU funds promotional campaigns on the overall perception of the EU in Poland, it is fair to say that the link between the two exists. According to available data, 47 per cent of Polish citizens have a positive image of the EU, with only Irish (58) and Bulgarian (51) populations being more pro-European, with the EU average at 34 (Standard Eurobarometer, 2016, p. 90). As it happens all three benefit from the EU funding and, consequently, have EU funding related campaigns in place. It supports the assumption that Cohesion policy related promotion positively impacts the image of the EU in a recipient country. Based on verified results of European Funds promotion, it is reasonable to assume that bigger use of corporate-style, multi-channel campaigns should be considered as one of the ways to increase the efficiency of the European communication. One must remember that the existing constraints of European Union's construction will not disappear. The reasons for which the EU has been so far unable to command more substantial interest of the news outlets will not change. It is hard to imagine EU Institutions being able to command media's attention, to make its narrative more newsworthy through the conflict creation. Direct, corporate style communication has the potential to limit the EU's dependence on the press and so does the new, online media.

Not only the share of the social media in the overall channel mix will grow. Due to the changing trends in their consumption, the composition of channels and ways to better mark the presence on available platforms will be constantly changing. One particular trend seems to be emerging: there's a clear increase in importance of the paid content on the social media, driven by the online platforms owners' willingness to increase their profits. According to available data, in Autumn 2016 as much as 80 per cent of marketing executives intended to place paid advertising on social media within a year as they discovered that so-called "generic" content (own created, free posts on the Facebook, Instagram, Twitter etc.) wouldn't lead to reach growth (Nayak, 2016).

It seems fair to assume that the European Institutions are prepared to adapt to the exigencies of the new communication environment, at least from the financial and human resources point of view. The European Commission's Directorate General for Communication budget limit (commitments) for 2017 is 210 million EUR (Draft General budget, 2016 , p. 803). In the past there were many promotional and educational programmes launched, like the "Europe for citizens" programme, with a somewhat generous yearly budget of 21,8 million EUR (2015 figure) (Implementing decision, 2014, p. 3) and rather broad goals, like promoting European values and peace - which raises questions about the efficiency of such programme. Trimming or abandoning inefficient programmes, subject to ex-post evaluation, would create a substantial financial cushion, allowing the Commission (other EU institutions likewise).

\section{Communication new language}

Increasing importance of the online social platforms means the necessity to adapt the language used in European communication. The need to avoid of the technical jargon has been recognised long time since. Yet in the current circumstances it is no not enough to skip the jargon and use plain language: the content of messages (the topic) must be 
adapted too. It should be more emotional (Maddalena, 2016, pp. 249-252). European institutions should not refrain from touching upon controversial issues such as corruption and tax evasion. While doing so, the European institutions should always portray themselves as taking the ordinary citizens' point of view, defending citizens' rights and interests (Grabbe, Lehne, 2016). This view is shared by other scholars: citizens nowadays instinctively seek the emotional connection and not only the rational argument. Using the functional angle is no longer enough (Waeraas, Byrkjeflot, 2012, pp. 186-206) to draw attention to the EU.

This is not to say that palpable material benefits of the EU should be disregarded. Addressing legitimate, real grievances, such as youth unemployment etc. also remains essential. The two approaches should go hand in hand. Putting it simply: the European Institutions should be able to communicate tangible "European" solutions to grave and current problems in an emotional way.

In parallel to the choice of channels and the proper language, the durability of communication is another crucial facto to be considered. Previous research has shown that the process of influencing public judgement on EU-related issues takes time. As explained by Elenbaas et al., newly received information must compete with prior beliefs (Elenbaas et al., 2012, pp. 728-755).

It is obvious that better communication alone will not suffice to address all the problems of the European Union. As Slovakia's junior European Minister Ivan Korcok put it, "it takes more than a PR agency or media strategy to win back trust" (Rettman, 2016). The EU's legitimacy must be first and foremost based on its real output to citizens. But this output must be communicated, in order to allow citizens to make their own judgement. In other words, to be possibly appreciated, the output must be seen in the first place. The communication does not create additional value in itself. Its meaning lies with helping understand the value of the community, explaining what the $\mathrm{EU}$ is responsible for.

\section{Conclusion}

Given the relatively low level of public support, the European Institutions are in dire need to improve reputation through reaching out to citizens with better communication. Available data lead to the conclusion that the previous methods of communicating Europe - focused on mediated messages and narratives - were not efficient. Over last years the public support for the EU and its institutions has been falling.

Despite the effort, the EU's past visibility in the mass media was very limited. EU institutions own experiences showed that alternative methods of connecting with citizens exist. Analysis of the European Funds' promotional campaigns supports this paper's hypothesis that direct, corporate-style communication is capable of bringing substantial results in terms of change in public perception. Such campaigns, based on the paid advertisement in different channels and circumventing the news outlets mediation, yielded noticeable results in terms of public support for a given idea.

While looking for new models of reaching citizens, European Institutions must react to the ever-changing environment of communication. The print press that has been dominating the media landscape for decades, is rapidly losing its importance. New media, 
like the online social platforms, are on the ascent - and they evolve quickly, becoming the major (if not most important) sources of information for citizens. EU Institutions' communication activity must adapt promptly, as (for example) corporate communication does. Further studies are needed to identify the most efficient channels and the language of public communication.

\section{Bibliography}

Action Plan to improve Communicating Europe by the Commission, SEC(2005) 985 final, (2005), European Commission.

Badanie omnibusowe skuteczności kampanii „Dobra informacja na dobry poczqtek” (2009), Pentor Research International, report commissioned by the Ministry of Regional Development.

Badanie poziomu dotarcia kampanii medialnej marki Fundusze Europejskie - „, Prawdziwe Historie” (2014), MillwardBrown, report commissioned by the Ministry of Infrastructure and Development.

Boomgarden H. G. et al. (2013), Across time and space: explaining variation in news coverage of the European Union, "European Journal of Political Research", no. 52.

Cohen N., There are liars and then there's Boris Johnson and Michael Gove, The Guardian, 25.06.2016, https://www.theguardian.com/commentisfree/2016/jun/25/boris-johnson-michael-gove-euliars, 13.07.2016.

Communication from the Commission to the Council, the European Parliament, The Economic and Social Committee and the Committee of the Regions on an Information and Communication Strategy for the European Union, COM(2002) 350 final (2002), European Commission.

Communicating Europe in partnership, COM(2007) 568 final (2007), European Commission.

Implementing decision of 8.12.2014 on the adoption of the 2015 work programme and the financing for the implementation of the Europe for Citizens programme, C(2014) 9220 final (2014), European Commission.

De Vreese C. (2003), Communicating Europe, Foreign Policy Centre, British Council Brussels, http:// fpc.org.uk/fsblob/89.pdf, 26.09.2016.

Draft General budget of the European Union for the financial year 2017 Volume 3 Section III Commission, COM(2016) 300-EN (2016), European Commission.

Elenbaas M. et al. (2012), The impact of information acquisition on EU performance judgements, "European Journal of Political Research", 51.

Grabbe H., Lehne S., Can the EU Survive Populism, Carnegie Europe, 14.06.2016, http://carnegieeurope.eu/2016/06/14/can-eu-survive-populism/j1vb, 19.06.2016.

Hard evidence: analysis shows extent of press bias towards Brexit, EU Referendum 2016, Media analysis from Loughborough University Centre for Research in Communication and Culture, Loughborough University (2016), http://blog.lboro.ac.uk/crcc/eu-referendum/hard-evidenceanalysis-shows-extent-press-bias-towards-brexit/, 24.07.2016.

Hodson H. (2016), How your Facebook feed will affect your Brexit vote, "New Scientist", 1.06, https://www.newscientist.com/article/2091552-how-your-facebook-feed-will-affect-your-brexitvote/, 21.11.2016.

Lodge J., Sarikakis K. (2013), Communicating Europe: political steps to facilitating a public sphere?, "Communication, Mediation and Culture in the Making of Europe", Il Mulino, Bologne.

Maćkowska R. (2006), Istota public relations w polityce, in: Public Relations w teorii i praktyce, eds. D. Tworzydło, T. Soliński, Wyższa Szkoła Informatyki i Zarządzania, Rzeszów.

Maddalena G. (2016), Political communication in the (iconic) Trump epoch, European View 15, http:// link.springer.com/article/10.1007\%2Fs12290-016-0403-9, 22.12.2016. 
Martins A. I. et al. (2012), Information Flow and Communication Deficit: Perceptions of BrusselsBased Correspondents and EU Officials, "Journal of European Integration", 34:4.

Mitchell A. et al. (2008), The Modern News Consumer, Pew Research Center, July 2016.

Monaghan E., Communicating Europe: the role of Organised Civil Society, "Journal of Contemporary European Research", vol. 4, no. 1.

Nayak M., Marketers seen spending more on paid social media ads: Gartner, Reuters, 3.10.2016, http://www.reuters.com/article/us-advertising-socialmedia-idUSKCN12326L, 7.10.2016.

Przybylski W. (2016), Czy Europejczycy myśla po europejsku?, „Instytut Idei”, 11.

Regulation 1303/2013 of the European Parliament and of the Council of 17 December 2013, OJ L 347.

Rettman A., EU wonders how to win back people's trust, EUobserver, 25.07.2016, https://euobserver. com/eu-presidency/134483, 3.11.2016.

Ryniejska-Kiełdanowicz M. (2007), Public relations Polski w okresie kandydowania do Unii Europejskiej, Wydawnictwo Uniwersytetu Wrocławskiego, Wrocław.

Special Eurobarometer 452, Media pluralism and democracy (2016), European Commission.

State of the Union (2016), European Commission.

Standard Eurobarometer 67 Full report (2007), European Commission.

Standard Eurobarometer 84, Media use in the European Union (2015), European Commission.

Standard Eurobarometer 85, Public opinion in the European Union (2016), European Commission.

Stroeker N., van der Graaf A., Buiskool B.-J. (2014), Communicating Europe to its citizens: state of affairs and prospects, European Parliament, Directorate-General for Internal Policies, Policy Department B: structural and cohesion policy, Study requested by the EP Committee on culture and education, PE 529.080, http://www.europarl.europa.eu/RegData/etudes/ STUD/2014/529080/IPOL_STU(2014)529080(SUM01)_EN.pdf, 17.10.2016.

The Commission's contribution to the period of reflection and beyond: Plan D for Democracy, Dialogue and Debate, COM(2005) 494 final (2005), European Commission.

The politics of anger, "The Economist", 2.07.2016.

White Paper on an European Communication Policy, COM(2006)35 final (2006), European Commission.

Waeraas, A., Byrkjeflot, H. (2012), Public sector organisations and reputation management: Five problems, International Public Management Journal, vol. 15.

Valentini C. (2013), Political Public Relations in the European Union: EU Reputation and Relationship Management Under Scrutiny, "Public Relations Journal", vol. 7, no. 4, Public Relations Society of America, https://www.researchgate.net/publication/259758691_Political_public_relations_in_the_European_Union_EU_reputation_and_relationship_management_under_scrutiny 19.12 .2016 .

Viner K., How technology disrupted the truth, 12/07/2016, "The Guardian”, https://www.theguardian. com/media/2016/jul/12/how-technology-disrupted-the-truth, 17.07.2016.

Vliegenthart R. et al. (2008), News coverage and support for European Integration 1990-2006, "International Journal of Public Opinion Research", vol. 20, no. 4, https://www.researchgate.net/publication/239903246_News_Coverage_and_Support_for_European_Integration_1990-2006, 13.11.2016.

\section{Wyzwania komunikacyjne Unii Europejskiej}

\section{Streszczenie}

W celu wsparcia odbudowy poparcia i zaufania społecznego do Unii Europejskiej, instytucje UE powinny dokonać zasadniczej modyfikacji strategii komunikacji. Niedawne wydarzenia polityczne, 
w tym zwłaszcza przeprowadzone w 2016 r. w Wielkiej Brytanii referendum na temat członkostwa w Unii Europejskiej, pokazały, że dotychczasowe sposoby nawiązania kontaktu z obywatelami nie dają już oczekiwanych rezultatów. Na podstawie dostępnych danych i ewaluacji ext-post kampanii promocyjnych, niniejszy artykuł rozważa możliwe sposoby ulepszenia sposobów, w jakie Unia Europejska kontaktuje się ze swoimi obywatelami. Autor konkluduje, że nacisk powinien zostać przeniesiony z komunikacji zapośredniczonej (przez tzw. tradycyjne media - prasę, radio, TV) na komunikację bezpośrednią, naśladującą korporacyjne kampanie reklamowe i wykorzystującą rosnące na znaczeniu platformy mediów społecznościowych. Własne doświadczenia instytucji Unii Europejskiej potwierdzają, że kampanie promocyjne wzorowane na korporacyjnych są skuteczne.

Słowa kluczowe: Unia Europejska, komunikacja, marketing polityczny, media społecznościowe 
